\title{
АФРИКАНСКИЙ ДЖИХАД СО СТАРЫМИ КОРНЯМИ?
}

Pérouse de Montclos M.-A. L'Afrique, nouvelle frontière du djihad? Paris: La Découverte, 2๑18. 239 p.

Перуз де Монкло М.-А. Африка, новая граница джихада? Париж: Ла Декуверт, 2Ф18. 239 с.

Деятельность террористических групп джихадистского толка в Африке южнее Сахары на протяжении длительного времени вызывает интерес западных специалистов. В ранее опубликованных на эту тему исследованиях подобная активность рассматривалась либо в рамках теории международного джихадистского заговора («кризисной дуги») [Hanne, Larabi 2015], либо, в свете всплеска международного терроризма в Сахеле, как следствие войны в Ливии 2011 года. Последняя оценивалась как открытие «ящика Пандоры» [Laurent 2013]. Оба подхода преуменьшают возможное влияние внутреннего конфликтного потенциала в сахаро-сахельском регионе, проводя параллели между ситуацией в Афганистане и в так называемом Сахелистане. Сахелистан - относительно новая и достаточно спорная концепция, призванная охарактеризовать новый фронт международного терроризма, стремящегося к мировому господству.

Оценки автора книги «Африка, новая граница джихада?» французского политолога Марка-Антуана Перуза де Монкло, признанного специалиста по африканской проблематике, директора по исследованиям французского Института исследования развития (IRD), выгодно отличается от перечисленных конвенциональных подходов. Он делает акцент на внутренней динамике противостояния в Сахеле, показывая эндогенную природу трёх действующих джихадистских группировок - АКМИ (АльКаида в странах исламского Магриба), Боко Харам и шебабов.

Главная идея, которую отстаивает автор, - «появление и эволюция АКМИ на севере Мали, шебабов в Сомали и Боко Харам в Нигерии в большей мере объясняются социальной ситуацией и соотношением сил на местном уровне, чем мировой “исламской революцией” (с. 17). Он также подвергает сомнению тезис о подчинении этих группировок руководству со стороны Аль-Каиды или ИГ (запрещены в России) из Сирии или Ирака. Автор указывает, что местные исламисты скорее пользуются хрупкостью африканских обществ и слабостью государственности в тех странах, в которых процветают эти движения.

При выработке позиции по отношению к противоправительственным движениям автор предостерегает от упрощённого подхода, даже если это удобно политикам, военным и международным чиновникам. Он отвергает существование пресловутого саудо-ваххабитского «исламистского интернационала» (с. 18), утверждая, что распространение в Африке джихадистских групп вызвано в значительной мере локальной динамикой (с. 53), которую необходимо детально анализировать не только в текущей фазе развития, но и в ретроспективе. 
Экскурс в совсем недавнее прошлое показывает, насколько колонизаторы умели, по мнению автора, сочетать применение военной силы со стратегиями кооптации, чтобы «укротить мятежников прошлого» (c. 57), в отличие от политики борьбы с терроризмом начала XXI века, которая делала ставку на репрессии, а не на длительную борьбу и диалог. Парадокс нынешней ситуации в том, что, с одной стороны, АКМИ, Боко Харам и шебабы получили распространение именно благодаря слабости правительств в бедных, лишённых инфраструктуры регионах ${ }^{1}$. С другой - эти джихадистские движения утверждают себя в качестве противников такого рода светских государств, унаследованных от периода колонизации (с. 80). Автор указывает, что основные причины, объясняющие распространение террористических группировок: - дисфункциональность официальных властей, их автократичность, низкое качество государственного управления, коррупция правящих классов в Африке попросту игнорируются (с. 103). Руководство Мали, например, отказывается допускать, что плохое управление - главная причина всех бед в регионе 2 .

Местные корни джихадистских конфликтов в Сахеле свидетельствуют об изъянах постколониальных моделей государственного устройства и методов управления, находящихся в отрыве от запросов значительной части населения. Возникшая лакуна была немедленно заполнена шариатскими представлениями о справедливом государственно-общественном устройстве. В итоге джихадисты пытаются предложить искажённую вооружённым насилием альтернативу официальной государственной модели. Между тем, как утверждает М.-А. Перуз де Монкло, политикам, принимающим решения, гораздо проще рассуждать о «глобальном исламистском заго- воре» и о «кризисной дуге», которая охватила Сахель, чем признавать местные корни конфликта (с. 103-105). Сам автор сомневается в способности групп типа АКМИ или Боко Харам захватить власть и удерживать контроль над целыми странами. Ограничением их возможностей выступают особенности демографической ситуации, географического пространства, а также уровень народного сопротивления и противоречий внутри политического ислама (с. 106). Он призывает не переоценивать противника и не отождествлять Сахель с Афганистаном.

Практикам антитеррористической борьбы представляется более простым способом дерадикализировать умы в киберпространстве (при том что на севере Мали и в целом в Сахеле сохраняются проблемы с электрификацией. $-A . C$.), чем заниматься решением глубинных проблем слабых и коррумпированных государств Африки. Затушёвывая местную специфику, упрощая до крайности социальную сложность конфликта и выдвигая на первый план жупел исламистского интернационала, эта «сага о великой террористической угрозе» (с. 122), подчёркивает автор, парадоксальным образом выгодна всем сторонам.

Африканским руководителям она позволяет оправдывать репрессии и требовать военной помощи. Джихадистам - преувеличивать свои возможности, а западным правительствам - легитимизировать вооружённую реакцию на распространение терроризма, обосновывая вмешательство в дела стран региона. Отказ от диалога с джихадистами побуждает к применению исключительно военной силы - решение, зачастую ведущее, по мнению Перуза де Монкло, к обострению конфликта (с. 151). Своё мнение автор обосновывает далее.

Обращаясь к опыту военной операции Франции на севере Мали (2013), исследо-

1 Последнее особенно характерно для Сахеля со всеми сопутствующими явлениями - коррупцией, отсутствием социальной справедливости, расколом элит, невозможностью выразить свою волю, репрессиями, иностранным вмешательством под предлогом защиты прав человека.

${ }^{2}$ Gouëset $C$. Au Mali, "la France prête trop d'attention au militaire pas assez au terreau du djihadisme” // L’Express. 19.05.2017. 
ватель предполагает, что вместо широкомасштабной операции можно было бы сдержать боевиков АКМИ и их союзников, преградив им путь на столицу и вынудив их к переговорам под угрозой бомбардировки их позиций в Томбукту (с. 152). Говоря об идеологической жёсткости исламистских проповедников, он одновременно отмечает их прагматизм вплоть до временного отказа от вооружённой борьбы, если соотношение сил неблагоприятно для них и вынуждает к «мирному сосуществованию». Подобная гибкость может открыть путь к переговорам с джихадистами - вариант, который, с точки зрения автора, успешно использовался французскими и британскими колониальными властями.

Нынешние западные политики, с ходу отвергая возможность диалога с группами, на которых навешивается ярлык террористов и фанатиков, лишают себя альтернативы мира, предпочитая вести «войну цивилизаций» (с. 154). Речь в конечном счёте идёт о способности и желании западных стран использовать глубокие теократические противоречия внутри современного африканского джихадизма. Правда, в этом случае попытки решения проблемы потребуют длительной вовлечённости, не совместимой с электоральными расчётами политиков, предпочитающих в угоду общественному мнению иллюзию «быстрого» военного решения.

В 2017 г. президент Франции Эммануэль Макрон высоко оценил решение своего предшественника о вмешательстве в Мали, требуя от армии решительных и быстрых побед ${ }^{3}$. С тех пор оценки перспектив стабилизации ситуации изменились. После полуторагодичного погружения в сахельскую проблематику французский руководитель, видимо, осознал, что ни о каком выходе с театра военных действий (ТВД) в обозримой перспективе не может быть и речи; что тематика борьбы с терроризмом может обсуждаться лишь в неопределённых временных категориях. В результате в феврале 2019 г. премьер-министр Э. ФИлипп заявил, что Франция останется «вместе с Мали столько, сколько необходимо» ${ }^{4}$.

Анализ финансовой составляющей джихадистских движений приводит Перуза де Монкло к выводу об отсутствии чётких границ между религиозными установками, политическими целями и целями обогащения, преследуемыми джихадистами. Жёсткость политики их подавления способствует политизации и криминализации деятельности таких группировок, особенно в слабых авторитарных государствах. Репрессии, пишет автор, являются питательной средой джихадизма, создавая образ мучеников (с. 154), загоняют джихадистов в подполье.

Джихадисты обеспечивают себе финансирование нелегальными средствами. Так, на севере Мали АКМИ стала взимать комиссионные с ранее существовавших сетей нелегальной торговли продовольствием, сигаретами, наркотиками. Ни АКМИ, ни Боко Харам, утверждает Перуз де Монкло, не создавали такого рода сетей. Последние существовали задолго до появления джихадистских группировок на африканской сцене, и они лишь встроились в уже сложившуюся систему. Скорее всего, если эти движения исчезнут, нелегальная торговля останется.

Спекуляция африканских правительств на угрозе джихадизма (как в годы «холодной войны» на «красной угрозе») позволяет им компенсировать дефицит демократии и оправдывать репрессии против оппозиции (с. 195). Приоритетное внимание автор обращает на коррупцию в силовых структурах, призванных искоренять джихадистов. Так, Франция официально поставляет оружие Нигерии и Чаду. Между тем в Чаде мятежники получают от кор-

\footnotetext{
${ }^{3}$ Macron E. Discours sur la base Barkhane [Speech at the base of Barkhane]. 2017. Le 19 Mai. URL: https://www.elysee.fr/emmanuel-macron/2017/05/19/discours-sur-la-base-barkhane (date of access: 10.10.2019).

${ }^{4}$ L'opération Barkhane pour stabiliser la zone sahélienne [The operation Barkhane to stabilize the Sahel]. 2019. URL: https://club.bruxelles2.eu/2019/03/loperation-barkhane-pour-stabiliser-la-zonesahelienne/ (date of access: 10.10.2019).
} 
румпированных офицеров украденное оружие в обмен на угнанные в Нигерии машины, которые затем перепродаются в Нджамене (с. 219-220).

Помимо жёсткой внутренней логики убедительность доводам автора придаёт обработка большого количества эмпирического материала, многочисленные интервью c представителями противоборствующих сторон. Например, в своё время высокопоставленные офицеры сил безопасности Нигерии в частном порядке признавались исследователю, что внесудебная расправа с духовным лидером Боко Харам (2009) была стратегической ошибкой и привела эту организацию сначала к уходу в подполье, а затем к терроризму (с. 204-205).

Рассматривая под разными углами зрения исследуемую тематику, автор позволяет читателю самому судить, существует ли единая линия фронта джихадистского толка в Африке, насколько она прочна и идеологически однородна; показывает, насколько соответствует реальности картина джихадистской угрозы, нарисованная СМИ и специалистами по борьбе с терроризмом.

Александр Сидоров

\section{Список литературы / References}

Hanne 0., Larabi G.(2015). Jihâd qu Sahel: Menaces, opération Barkhane, coopération régionale [Jihad in the Sahel : Threats, Barkhane operation, regional cooperation]. Paris: Éd. Bernard Giovanangeli. $190 \mathrm{p}$.

Laurent S. (2013). Sahelistan: de la Libye au Mali, au coeur du nouveau jihad [Sahelistan: from Libya to Mali, in the heart of the new jihad] Paris: Seuil. 370 p. 